DOI https://doi.org/10.30525/978-9934-588-90-7-64

\title{
ОСОБЛИВОСТІ ПЕРЕКЛАДУ ФІЛОСОФСЬКИХ ТЕКСТІВ
}

\author{
Редчиць Т. В. \\ кандидат філологічних наук, \\ дочент кафедри прикладної лінгвістики та перекладу \\ Черкаський державний технологічний університет \\ м. Черкаси, Україна
}

Одним 3 важливих методологічних аспектів «лінгвістичного повороту» в філософії стало усвідомлення того, що філософія не лише аналізує мовні форми вираження думки, а й те, що вона сама $є$ мовою зі своєю структурою, правилами, зі своїм термінологічним апаратом. Філософія - це абсолютно особлива лінгвокультурна сфера зі стрункою системою понять і складними міжтекстовими зв'язками.

Розвиток філософії завжди супроводжується оновленням філософської мови, опрацюванням певних мовних ресурсів. Філософія, як ми знаємо, - це «мистецтво формувати, винаходити, виготовляти концепти» [2, с. 10], причому саме в такому, технологічному сенсі, як зазначав Дельоз («La philosophie est l'art de former, d'inventer, de fabriquer des concepts» [2]). Концепти - це філософська реальність, тому чіткість понять, точність (або, навпаки, навмисна метафоричність і багатозначність) слововживання - речі цілком взаємопов'язані. У кожного способу усвідомлення дійсності $\epsilon$ своя мова, яка дозволяє адекватно висловлювати певну розумову парадигму, - мова класичного раціоналізму, екзистенціалізму або постмодернізму. Однак акт філософствування здійснюється завжди на конкретній мові - французькій, німецькій, російській, тощо.

Сучасна вітчизняна філософія приймає та адаптує, іноді з великими труднощами, великий потік понять, які формувалися протягом тривалого часу в феноменології, екзистенціалізмі, аналітичної філософії, структуралізмі та постструктуралізмі. Ці поняття пройшли довгий етап кристалізації на Заході і водночас з'явилися в українському культурному просторі в кінці минулого століття.

Тому роль перекладу для розвитку філософії важко переоцінити. В міжкультурній комунікації важливого значення набуває переклад філософських текстів, за допомогою якого здійснюється обмін ідеями та, внаслідок цього, формується категоріальний апарат філософії. 
Проблематикою перекладу філософських текстів займалися: Н. Автономова, В. Курєнной, М. Лебедев, М. Соболева, А. Гірш, У. Й. Шнайдер, та ін.

В українській філософській літературі цій проблематиці присвячені праці філософів-перекладачів I. Бичка, В. Срмоленка, А. Срмоленка, А. Богачова, М. Култаєвої, С. Йосипенка, С. Кошарного, В. Кебуладзе, В. Малахова, Л. Ситниченко, О. Хоми та інших. Теоретичною проблемою перекладу філософських текстів українською мовою займалися П.В. Демешко, В. Горський, О. Хома.

Переклад філософського тексту може бути розглянутий лише у рамках діалогу національно-культурних світів і філософських традицій. П. Тороп вказує, що «Чистих текстів в культурі практично не існує, текстова пам'ять $\epsilon$ у автора, перекладача і читача» [4, с. 13]. Переклади стають складовою частиною національної культури, сприяють іiі збагаченню і розвитку, що призводить до зближення різних розумових систем. Як відомо, в процесі перекладу з грецької і латини формувався філософський категоріальний апарат в нових мовах починаючи з епохи Відродження.

Робота 3 перекладом передбачає особливу читацьку установку: читач весь час повинен пам'ятати, що він має справу лише 3 текстомпосередником, який передає лише певне уявлення про текст оригіналу (це відбувається навіть 3 кращими перекладними текстами, оскільки перекладач дає свою інтерпретацію того, що він побачив і зрозумів в оригіналі, а 3 того, що він побачив і зрозумів, не все можна передати засобами мови).

Тут має значення цілий ряд факторів: майстерність перекладача як письменника мовою перекладу, рівень володіння ним мовою оригіналу, наявність спеціальних знань в галузі, в якій здійснюється переклад, загальна ерудиція, ступінь «перекладності» оригіналу на інші мови та ін.

Переклад, особливо філософських текстів, несе в собі сліди численних трансформацій сенсу i форми, втрат і додавань, часом вимушених, часом навмисних, іноді усвідомлених, хоча, ймовірно, частіше неусвідомлюваних. Тому оцінка будь-якого перекладу передбачає врахування великої кількості параметрів $[5,97]$.

Створення філософської мови і створення філософської системи тривалий історичний процес. Так, Дерріда спирається на Гайдеггера, Гайдеггер - на Гуссерля, а Гуссерль - на Декарта і т.

Можна, також, не сумніватися, що роль перекладу в створенні концептуальних систем і в формуванні мови філософії як такої важко переоцінити.

Так, в одній зі своїх книг Н. Автономова говорить про те, що була змушена «винайти» слово дискурсія (в оригіналі у Фуко $є$ тільки 
discours), щоб не вводити в оману читача. Причиною появи такого роду «винаходу» послужило те, що саме в творчості Фуко знаходять відображення два найважливіші етапи розвитку поняття discours: 1) логіко-лінгвістичне розгортання уявлення і 2) соціально-регламентоване висловлювання, яке не має відношення ні до логіки, ні до лінгвістики [1, с. 376-385]. В цьому випадку народження перекладацького новоутворення, яке було відсутнє як в мові оригіналу, так і в мові російської та української філософії кінця 70-х років ХХ ст., було зумовлено необхідністю розвести для читача різні значення французького слова. I, як результат, текст був адаптований, став більш зрозумілим.

Як зазначає у своєму дисертаційному дослідженні П.В. Демешко «філософські тексти як відображення світорозуміння автора в перекладознавчому плані характеризуються не лише складністю синтаксичних конструкцій чи термінології - складність перекладу зумовлена способом мислення .... філософів, що значною мірою знаходиться під впливом мови, адже філософський текст містить не універсальну інформацію про об'єктивний світ, а є результатом специфічного та індивідуального сприйняття та осмислення світу філософом [3, с. 5]».

Можна сказати, що сучасна вітчизняна філософія продовжує пошук своєї мови, здатної відображати не лише поліфонію, але й глибину та суперечливість сучасного філософського мислення.

Оскільки недостатньою з'ясована специфіка філософських текстів як лінгвістичних утворень, то залишається недослідженою проблема місця філософського тексту серед інших типів текстів. Питання про адекватність перекладу в сучасній культурі відкрито для подальшого критичного розгляду.

\section{Література:}

1. Автономова Н.С. Познание и перевод. Опыты философии языка. М. : РОССПЭН, 2008. - 704 c.

2. Галиева А.М., Ибрагимова 3.3. Перевод и проблема отечественного философского языка. URL: http://www.perevodi-problema-otechestvennogo-filosofskogo-yaz-ka.pdf (дата звернення: 20.10.2020).

3. П.В. Демешко. Герменевтичні аспекти українського перекладу німецьких філософських текстів хх століття: автореф. дис. ... канд. філол. наук: 10.02.16 Київ, 2009. 17 с.

4. Тороп П. Тотальный перевод. - Тарту: Изд-во Тарт. ун-та, 1995. $-220 \mathrm{c}$. 
5. Olga Herfelder-Polschin: Verbranntes Denken - verbrannte Sprache. Übersetzung und Rezeption des philosophischen Werkes von N. Berdjaev in Deutschland. Berlin 2013. S. 97.

DOI https://doi.org/10.30525/978-9934-588-90-7-65

\title{
НЕОКЛАСИЦИЗМ І АКМЕЇЗМ: ГЕРОЙ У ВИБРАНІЙ ПОЕЗІЇ МАКСИМА РИЛЬСЬКОГО І МИКОЛИ ГУМІЛЬОВА (СИМВОЛ, ПЕРЕКЛАДОЗНАВЧИЙ АСПЕКТ)
}

\author{
Смольницька О. О. \\ кандидат філософських наук, член ІСОМ, \\ провідний науковий співробітник \\ Киїський літературно-меморіальний музей Максима Рильського \\ м. Київ, Украӥна
}

Подібні риси українського неокласицизму і російського акмеїзму (як і схожість «п'ятірного грона» з іншими течіями тощо) вже виокремлювались у вітчизняній гуманітаристиці [8-11], проте інтуїтивний поетичний діалог Миколи Гумільова (1886-1921) і раннього Максима Рильського (1895-1964) іще докладно не розглядався. Відтак, пропонується здійснити компаративний аналіз.

Матеріал аналізу: вибрана рання лірика М. Рильського, оригінал вірша М. Гумільова «Старый конквистадор» (1908 р., зі збірки 1918 р. «Жемчуга», у перекладі М. Стріхи назва - «Перлини»; до того книга виходила 1910 р. [12, с. 725]) та україномовні поетичні переклади: 1) М. Стріхи, 2) неопублікований переклад авторки цих рядків (див. додаток). Обидва переклади здійснені незалежно один від одного. Пропонується компаративний, символогічний, текстологічний, перекладознавчий аналіз. Переклад М. Стріхи береться до уваги як переважно точний; до того ж, цей український текст демонструє зв'язок літературних поколінь - неокласиків та їхніх учнів.

Нахил неокласиків до точності, елітарних здобутків парнасизму звідси про мороз як «душу парнаського співця» [3, с. 217] (в оригіналі ці слова - 3 авторською розрядкою [6, с. 57]) зумовлює творчий пошук М. Рильським і поетові вислови на кшталт у «Срібному сонеті»: «Цей вечір, замкнений в холодному спокої, / Ясний, докінчений нагадує сонет...» [6, с. 85]. Або «сьомий неокласик» І. Качуровський (19182013), аналізуючи «В високій келії, самотньо-таємничій...» і докладно 